\title{
聴器癌11例の臨床的検討
}

\author{
佐藤 公輝 - 田中 克彦・吉村 理 \\ 酒井昇・大沼 秀行・寺山吉彦
}

\section{Clinical Study of Carcinomas of External Ear Canal and Middle Ear}

\author{
Masaki Satoh, Katsuhiko Tanaka, Tadashi Yoshimura, \\ Noboru Sakai, Hideyuki Ohnuma and Yoshihiko Terayama \\ (Hokkaido University)
}

It is well known that the incidence of carcinoma in the external and middle ear is very low and that the prognosis is poor, especially for middle ear carcinomas.

During the past 15 years, 11 patients with carcinoma of the middle or external ear have been treated in the Department of Otolaryngology of Hokkaido University Hospital. Seven carcinomas were in the external auditory canal and four in the middle ear. The histopathologic diagnosis was squamous cell carcinoma in eight, and adenoid cystic carcinoma in three patients. Therapy was mainly a combination of irradiation and surgical resection. Three patients also received CDDP.

Our results revealed that the prognosis for external ear carcinoma is much better than for middle ear carcinoma. All four patients with middle ear carcinoma died, but five of the seven patients with external ear carcinoma are alive and free of the disease, at least one and a half year after surgery.

Carcinoma of the external ear canal tended to show radial extension, involving the soft tissues adjacent to the canal rather than extending longitudinally towards the middle ear.

The principal factor in the poor prognosis of middle ear carcinoma is ascribed to the destruction of the skull base, while that of the external auditory canal is deep invasion of the soft tissue around the canal.

Key words: carcinoma, external auditory canal, middle ear, clinical study, case report

\section{緒言}

聴器癌は，頭頸部腫瘍のなかでも比較的稀な あのである. 耳介癌, 外耳道癌, 中耳癌に分類 されるが，特に中耳癌は極めて予後不良であ る. 発症初期には, 慢性中耳炎・外耳道揤等と の鑑別が困難である一方，その治療法は個々の
症例でとに選択されているのが現状である.

過去15年間における聴器癌11例を臨床的に検 討したので報告する.

対 象

昭和 47 年より昭和 61 年までの 15 年間に当科に おいて聴器癌と診断されたのは，男 4 例・女 7 
例の計11例である。年齢は33才から74才で平均 年齢51. 5 才であった。

原発部位別では，外耳道癌 7 例，中耳癌 4 例 であり耳介癌はなかった。

症例

次に外耳道癌の生存例と広範囲進展例を呈示 する。

症 例: 44才 女性（症例10）

主 訴: 右耳痛・右耳漏

初診：昭和 61 年 8 月 8 日

既往歴・家族歴：特記すべき事なし.

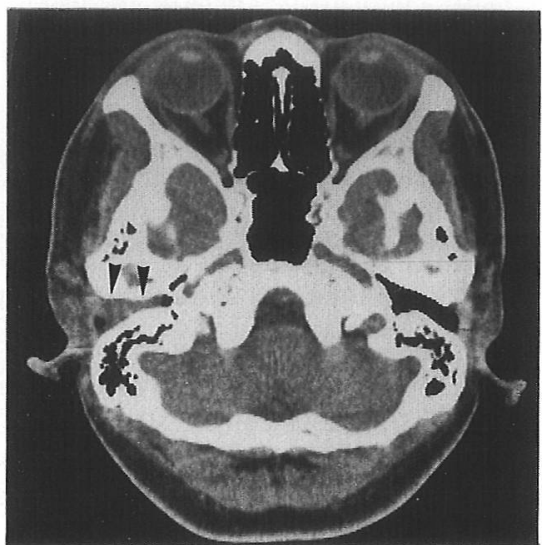

a：右外耳道は喱瘍で充満している(

図 1 症例10
現病歴：昭和 61 年 5 月頃より右耳搔㾕感あ り，耳漏も出現したため，7月17日近医耳鼻科 受診. 同院にて外耳道腫瘤を指摘され，生検の 結果扁平上皮癌之診断された。

同年 8 月 8 日当科受䛦. 外耳道は日色の柔引 かい腫瘤が充満していた.鼓膜は観察できない。 䉼層写真及び CT では，外耳道は腫瘍陰影で充 満しているが，中鼓室・乳突洞への浸潤はみら れなかった(図 1). 聴力は $46 \mathrm{~dB}$ の伝音難聴で あった。めまい症状はなく，眼振も認めない。 顔面神経麻痺, 頸部リンパ節腫脹なし.

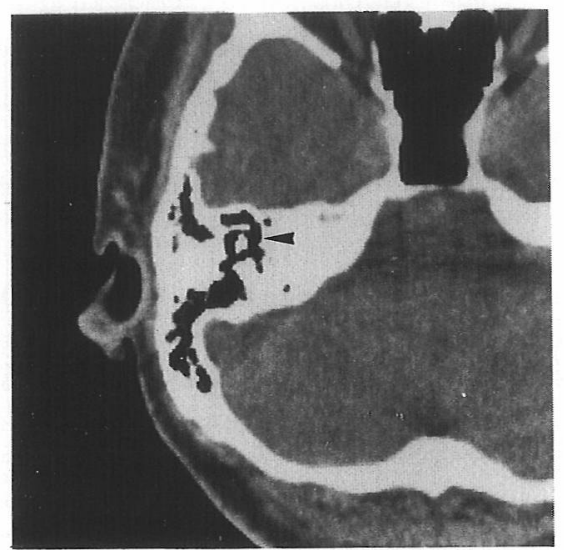

$\mathrm{b}$ ：乳突洞，上鼓室に陰影はな，耳小 骨むみえる(

\section{CT 所見}

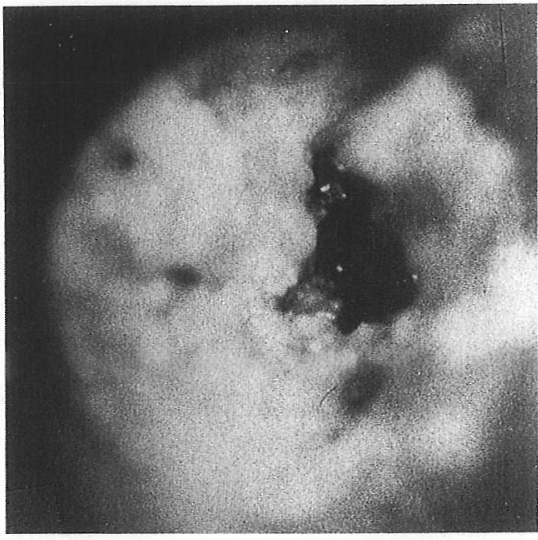

$\mathrm{b}$ : 外耳道内は出血性の肉芽組織で充満 している。

図 2 症例11 局所所見 
右外耳道癌之彰断し, 右外耳道を中心に $40 \mathrm{~Gy}$ 照射. 9 月 27 日右中耳根本術施行. 腫痬は中鼓 室・乳突洞に至ってはいなかったが，外耳道骨 の一部はもろく，外耳道皮膚を全摘するととも に骨部外耳道の大半を切除した。

術後，予防的にシスプラチン，ペプレオによ る化学療法を1クール施行した後，11月27日退 院.

現在まで再発なく経過良好である.

症 例：42才 女性（症例11）

主 訴: 右耳痛

初 䛦：昭和 61 年 7 月 30 日

既往歴・家族歴：特記すべき事なし。

現病歴：昭和 61 年 3 月より右耳漏あり，徐々 に耳痛を伴ってきたため同年 7 月 30 日当科初 診. 右耳後部の腫脤を認め, 外耳道は肉芽状組 織で充満していた(図 2)。CT では，耳介付着 部が腫脹し，環椎横突起近傍に異常陰影を認め る(図 3 ). 聴力検查では $60 \mathrm{~dB}$ の伝音難聴を認 めた。頸部りンパ節腫脹はない，外耳道内腫瘤 の生検により扁平上皮癌と䛦断された。

8 月 15 日より局所に $40 \mathrm{~Gy}$ 照射，9月26日入 院し，10月 6 日，右耳下腺全摘・右頸部郭清を 含めて右側頭骨再全摘を施行した，摘出標本に よる病理学的検索によると，外耳道骨全周・耳
介部皮膚・耳下腺・頸椎横突起近傍結合組織に 腫瘍の浸潤を認めたが，鼓室・鼓膜に腫瘍細胞 はなかった。

術後シスプラチン，ペプレオによる化学療法 を 1 クール施行したが， 3 ケ月後，横突起部肉 芽より再発が確認され，50 Gy の追加照射とと もに温熱療法を 9 回行った。しかしながら腫瘍 は副咽頭を中心に広範に浸潤して下位脳神経麻 痺をきたし，昭和62年 8 月26日呼吸停止にて死 亡した。

\section{結 果}

表 1 は全症例についての概要である。

初発耳症状は，耳痛 5 例，耳漏 3 例，外耳道 腫瘤が 2 例, 外耳道異常感が 1 例で, 他に耳搔 痒感が 3 例ある。乙の 3 例のうち症例 $2 ， 4$ は 当科受診の 10 年以上も前から搔㾕感があったと いう。症例 3 は，マッチ軸を耳内に入れたまま 取れなくなり，それ以後数ヶ月にわたって耳痛 ととあに大量の耳漏が持続していたものであ る。

主訴としては耳痛・耳漏が 8 例，外耳道腫瘤 が 5 例顔面神経麻痺が 1 例である。聴力検查で 難聴は 7 例（感音 1 ，伝音 4 ，混合 2 ）に確認 された，局所所見では，外耳道内の異常肉芽， 外耳道腫脹・腫瘤がそれぞれ 7 例で，耳後部㾞

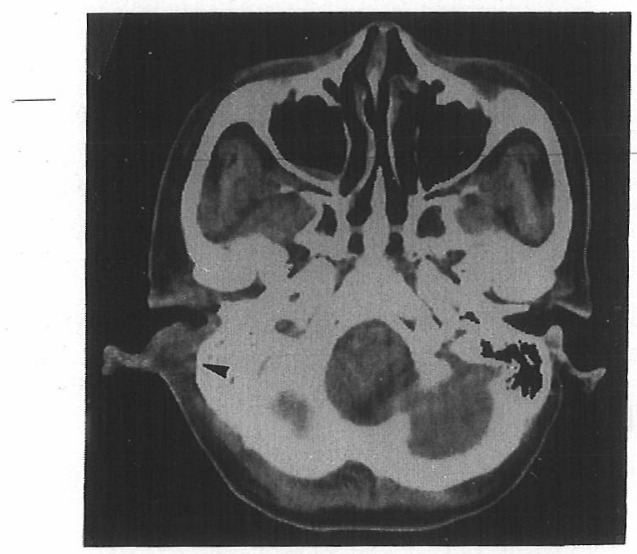

a : 右外耳道壁が全周にわたり肥厚し, 耳介付着部に浸潤性陰影を認める $(-)$.

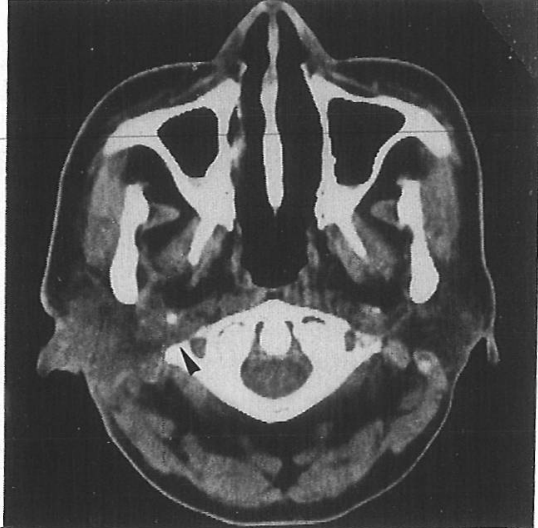

$\mathrm{b}$ :さらに下方のレベルでは，耳下腺の 大半が腫瘍におきかわり，副咽頭腔 に及んでいる(ー)。

図 3 症例11 CT 所見 
孔形成が 2 例である．画像診断上側頭骨になん らかの骨破壊をみたものが 7 例あった。初晾時 に頸部リンパ節腫脹をみたものはなかった。

さて，症例には耳科的既往をむつものが少な くない, 慢性中耳炎 3 例, 外耳道揤 2 例, 外耳 道炎 2 例で，11例中 7 例に及ぶ。なお，慢性中 耳炎の既往をむつ 3 例のうち症例 1 は20才時に 耳性䯣膜炎の診断で中耳根本術を受けており， 症例 8 は 9 才時に中耳半根治術を受けている.

診断は生検による病理組織学的䛦断によっ た. 外耳道の異常肉芽を生検したもの 6 例，外 耳道生検で確診の得られなかったものなど手術 時の摘出材料によるあの 5 例である.（5 例中, 他院で手術された 1 例を除く 4 例は改めて摘出 術を行った.)

初診より確診までの期間は多くが 1 ケ月以内 であるが，複数回の生検を要して時間のかかっ たものあある。

11例の病理組織は扁平上皮癌が 8 例, 腺様囊 胞癌が 3 例で (表 2 ), 外耳道癌が 7 例, 中耳癌 が 4 例である.

手術時所見を参考にした主な進展部位を表 3 にまとめた。外耳道癌では，耳下腺・顎関節な ど耳周囲組織に浸潤していたものが 7 例中 4 例 あったが，中鼓室に深く進展した例はなかった. 中耳癌では，全例が頭蓋底の破壊をきたした が，外耳道癌にみられるような耳周囲組織への
進展は必ずしも伴わず，症例 $1 ， 3$ では主に頭 蓋内への浸潤をみただけで，外耳周囲への拡大 進展はみられなかった。

治療は原則として手術を主体とし，放射線治

表 2 聴器癌11例の部位別病理組織

\begin{tabular}{c|c|c|c}
\hline & 外耳道癌 & 中 耳 癌 & 計 \\
\hline 扁平上皮癌 & 5 & 3 & 8 \\
腺様霊胞癌 & 2 & 1 & 3 \\
\hline 計 & 7 & 4 & 11
\end{tabular}

表 3 聴器癌11例の主な進展部位（手術時）

\begin{tabular}{|c|c|c|c|c|}
\hline & & & 外耳道癌 & 中耳癌 \\
\hline 外 & 耳 & 道 & 全例 & ) \\
\hline 乳 & 突 & 洞 & 3 & 全例 \\
\hline 鼓 & & 室 & 0 & 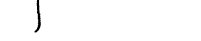 \\
\hline 耳 & 下 & 腺 & 4 & 1 \\
\hline 顎 & 関 & 節 & 2 & 1 \\
\hline 頸 & & 部 & 2 & 1 \\
\hline & 盖 & 底 & ( $\stackrel{1}{1}$ 状静脈洞) & （主に鼓室天蓋） \\
\hline
\end{tabular}

表 4 聴器癌11例の転帰

\begin{tabular}{c|c|c}
\hline & 生 存 & 死 亡 \\
\hline 外耳道癌 & 5 & 2 \\
中耳 癌 & 0 & 4 \\
\hline 期 間 & 8 ケ月〜10年 & 4 ケ月〜 1 年 6 ケ月
\end{tabular}

表 1 症例概要

\begin{tabular}{|c|c|c|c|c|c|c|c|}
\hline 症例 & 性別 & 年齢 & 原 発 & 病 理 & 既 往 & 予 後 & 経 過 \\
\hline 1 & $\hat{0}$ & 39 & 中 耳 & 扁平上皮癌 & 慢性中耳炎 & 腫瘍死 & $1 \mathrm{Y} 6 \mathrm{M}$ \\
\hline 2 & 우 & 62 & 中 耳 & 腺様霊胞癌 & 外耳道㽿 & 腫瘍死 & $9 \mathrm{M}$ \\
\hline 3 & 우 & 74 & 中 耳 & 扁平上皮癌 & 外耳道炎 & 腫瘍死 & $4 \mathrm{M}$ \\
\hline 4 & 우 & 33 & 外耳道 & 腺様霊胞癌 & 外耳道 揤 & 生 存 & $10 \mathrm{Y}$ \\
\hline 5 & $\hat{o}$ & 74 & 外耳道 & 扁平上皮癌 & 外耳道炎 & 生 存 & $6 \mathrm{Y} 7 \mathrm{M}$ \\
\hline 6 & $\hat{\delta}$ & 57 & 外耳道 & 扁平上皮癌 & & 生 存 & $4 \mathrm{Y} \quad 4 \mathrm{M}$ \\
\hline 7 & 우 & 36 & 外耳道 & 腺様霊胞癌 & & 生 存 & $1 \mathrm{Y} 10 \mathrm{M}$ \\
\hline 8 & $\hat{0}$ & 57 & 中 耳 & 扁平上皮癌 & 慢性中耳炎 & 腫瘍死 & $10 \mathrm{M}$ \\
\hline 9 & 우 & 48 & 外耳道 & 扁平上皮癌 & 慢性中耳炎 & 腫瘍死 & $1 \mathrm{Y}$ \\
\hline 10 & 우 & 44 & 外耳道 & 扁平上皮癌 & & 生 存 & $1 \mathrm{Y} 7 \mathrm{M}$ \\
\hline 11 & 우 & 42 & 外耳道 & 扁平上皮癌 & & 腫瘍死 & $1 \mathrm{Y}$ \\
\hline
\end{tabular}


療，化学療法を適宜併用した。

症例 1 は, 中耳根治術の既往があり他院で再 手術を受けた時に中耳癌と診断されたもので， 当科初䛦時既に頭蓋底の破壊があり放射線治療 のみとした，症例 2 は，乙れあ頭蓋底破壊を伴 う腺様囊胞癌で減荷術のみ施行. 症例 4,5 は 外耳道に限局する扁平上皮癌で手術のみ施行.

症例 7 は腺様囊胞癌で摘出術とと屯にシスプラ チン，アドリアマイシンによる化学療法を併用 した。 その他は，術前 40〜50 Gy 照射の後手術 施行. 症例によりさらに 40～50 Gy の術後照射 を追加した，症例10，11の 2 例は，さらにシス プラチン，ペプレオによる化学療法を加えた.

手術は腫瘍の部位及び範囲により様々で，単 純な外耳道腫瘍摘出術から, 外耳道部分切除, 乳突削開，中耳根治，拡大中耳根治，側頭骨亜 全摘などであり，症例により頸部郭清を加え た。

自験例の予後であるが，中耳癌においては残 念ながら生存例はない. 外耳道癌については, 7 例中 5 例が生存中である. ことに症例 4,5 , 6 はかなり長期にわたる経過良好例で, 治瘾之 判定してよいであろう.また, 中耳癌を含めた腫 瘍死例 6 例は全例 2 年以内に死亡しており， 5 例は 1 年以内という短期であった（表 1 , 表 4).

\section{考察}

聴器癌の性比については, 自験例のように女 性に多くみられたとする報告ああるが”，一般 には男性に多いとされる ${ }^{233}$. 隠明寺ら ${ }^{4)}$ は， 187例の側頭骨悪性腫瘍（うち癌腫117例）を集 計し, 癌腫での発生率は男性が女性の約 1.5 倍 であったという。

好発年齢は50〜60才台という報告が多い.

聴器癌の誘因として以前より, 慢性中耳炎が 指摘されている。聴器癌の70 $80 \%$ に慢性中耳 炎の既往があるといわれ，慢性中耳炎の活動性 炎症病態，及び耳漏による中耳・外耳への慢性 的な刺激が聴器癌発症の誘因として重要である という。これらの既往が聴器癌の早期診断を妨 げている一つの要因でもある.
自験例でむ 3 例に慢性中耳炎の既往がある. うち 2 例はかなり以前に手術を施行されてお り，誘因としてどの程度関与したかは疑問であ るが，一方では中耳根治術後に発症した聴器癌 の報告屯ある ${ }^{577)}$. 馬場ら ${ }^{8)}$ によると1960年から 1971年の本邦文献例23例中，中耳根治術・鼓室 形成術後に発生したものが 6 例あり，また，松 岡ら ${ }^{9)}$ は中耳根本術 5 年後に乳頭腫となり，さ らに 5 ケ月後に扁平上皮癌へと変性した例を経 験したという。

症例 3 は聴器癌発症の誘因を考えるうえで與 味深い. マッチ軸を耳内に入れてから耳漏持続 し，その 6 ケ月後の当科初診時には既に外耳道 は肉芽で充満し中耳天蓋の骨破壊を伴ってい た．それ以前より無症候性の腫瘍の存在した可 能性もあるが，少なくとあマッチ軸による炎症 機転が腫瘍の発症または進展を促進したと考え られる。

耳介癌は農業従事者に多発し，太陽光線が重 要な因子と考えられているが ${ }^{10)}$ ，自験例には耳 介癌はなかった。

聴器癌の主症状は，耳漏・耳痛・外耳道腫瘤 など，耳疾患一般にみられるすのと共通するた め，慢性中耳炎 - 外耳道節との鑑別が比較的团 難である. Rossenwasser ${ }^{11)}$ は聴器癌早期 発見 の立場から本症を疑うべき症状として，1）難 治性の外耳道炎，2）易出血性，3）顔面神経 麻㽻，4）激しい耳痛，の 4 症状をあげてい る。原田ら ${ }^{12)}$ は，耳搔棒感が外耳道癌に多い のは特徵的であろうともいっている。

いずれにせよ，確定崄断は病理学的になされ るので, 耳痛・耳漏の持続，外耳道肉芽の増生， 外耳道腫瘤の経過に注意し，難治性の場合には 早期に生検を試みることが最あ重要である。生 検部位は外耳道内腫瘤, 肉芽組織でよいが，初 回の生検で確診のつかないととあ少なくない. 安斎ら ${ }^{13)}$ は, 慢性炎症に隠蔽された悪性腫瘍を 早期に診断することが予後を左右する重要なポ イントと述べており，自験例において 4 例が手 術時材料により診断されたでとく，外科的アプ 
ローチによる診断材料採取も時には必要と考え る.

病理組織学的には，扁平上皮癌が大部分であ る. Lewis ら ${ }^{14)}$ は75\%，Boland ら ${ }^{15)}$ は93\% を占めると報告している。組織型及びその発生 率は，耳介，外耳道，中耳之その原発部位によ り若干の差があるものの，扁平上皮癌が全体の ほぼ 7 割以上を占めている。 その他は，腺様囊 胞癌，基底細胞癌等である。自験例では，腺様 囊胞癌が 3 例で，他 8 例はすべて扁平上皮癌で あった. 原田ら ${ }^{12)} や ，$ 梅谷ら $^{16)}$ 屯，聴器悪性 腫瘍の約 $1 / 4$ が腺様囊胞癌であったという.

耳介発生例がなかったためか，同部に発生率 の高い14) 基底細胞癌等はなかった.

聴器癌の予後は, 外耳道癌で 5 年生存率が50 ～60\% ${ }^{17)}$ ，中耳癌で $25 \%$ 前後であるという ${ }^{18)}$.

自験例でも外耳道癌 7 例については 5 例が生存 しているが，残念ながら中耳癌で生存中のもの はない. 斉藤ら ${ }^{19)}$ は中耳癌剖検例の側頭骨病理 所見を報告し，中耳癌予後不良の要因は，病変 の拡大が急速であるうえに重要臟器に隣接し， 潹部のため放射線治療が効きにくいととによる 之述べている，我々の中耳癌症例も全例頭蓋内 進展をきたし，減荷術とともに放射線治療を施 行したがその効果は不十分であった。

白幡 ${ }^{20)}$ は，乙のような深部進展例と予後の関 係に注目し, 聴器癌を聴器内癌と聴器外癌とに 分類している．外耳道狭部を境として腫瘍の主 在部位により内外に分けたものであるが，その 理由として，1）癌腫が中耳腔を占拠している 場合とそうでない場合とでは予後が明らかに異 なる，2）中耳癌と外耳道深部癌では原発部位 がさだかでない場合が多い，の 2 点をあげてい る. 切替ら ${ }^{21)}$ は, 中耳癌の進展方向を調へ，中 耳癌をさらに内方型と外方型とに分類してい る. これらの分類法は, 深部（内方）進展例の 制御が極めて困難であって，墚部（内方）進展 が予後に直結するとの認識からなされたもので ある ${ }^{22223)}$. 実際, 進行例では原発部位の判定が 困難であるととも少なくなく ${ }^{13)}$ ，臨床的には原
発部位別の分類よりも実用的かもしれない.

一方，外耳道癌は外耳道にそった長軸方向に 進展しやすいともいわれるが20)，症例 4, 5, 7,9， 11は，外耳道骨を破壊して乳突洞・耳周囲軟部 組織・耳下腺・顎関節などへの浸潤をみたもの の，中鼓室に腫痬は存在しなかった。乙れらの 例のうちには，鼓膜に接してその外耳道側は腫 瘍であるが中鼓室に浸潤を認めない例もあり， 外耳道から中耳腔への腫瘍の浸潤に対し，鼓膜 が防御壁となっているように思われた。むちろ ん，外耳道深部原発例が早期に中鼓室に侵入し て中耳癌と判定されている例のある可能性はあ るが，少なくとも外耳道癌の浅部（白幡 ${ }^{20)} の$ いう聴器外癌）に原発したものは，外耳道後壁 の破壊，乳突洞への侵入，顎関節・耳下腺への 浸潤などのように，むしろ，外耳孔を中心とし て浅層を放射状に拡大する傾向がみられた。

頸部リンパ節転移は，それほど多くなく，自 験例でも初䛦時に頸部リンパ節腫脹を触知した 屯のはない，経過期間を含めると中耳癌の 1 例 外耳道癌の 1 例に頸部転移がみられた。

聴器癌の治療は, 外耳道癌については放射線 が有効ではあるが，単独では不十分であり，本 田 ${ }^{24)}$, 齋藤 ${ }^{25)}$, は摘出術の必要性を強調し ている．外耳道癌に対する放射線の有効性は自 験例においてもみとめられる所であるが，腺様 囊胞癌や，深部進展例などがあって，基本的に は手術治療を中心とするのがよいと考えた，自 験例では，外耳道癌 7 例全例に摘出術を施行 し，4例に放射線を併用，うち 2 例を含む 3 例 に化学療法を追加した。

症例11（中鼓室に腫瘍はなかったが外耳道下 壁を破壊し頸椎近傍にまで浸潤していた例）に みられるごとく, 外耳道癌にあっては，外耳孔 周囲への拡大範囲が予後のポイントになるであ ろう. 症例 4，5のように，腫瘍が比較的限局 し外科的切除が可能であれば，充分に良好な予 後が見込まれる。

中耳癌の治療法については古くから数多くの

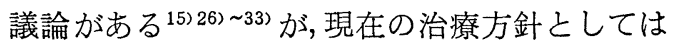


Conley ら ${ }^{27)}$ に代表される一次的側頭骨亜全摘 を中心とするものと, Hanna ら ${ }^{29)}$, Fairman ${ }^{33}$ に代表される放射線と側頭骨腫瘍の逐次鎮除の 併用療法に 2 大別される.

本邦に打いても手術治療が原則とされる。斉 藤ら ${ }^{34)}$ は進行癌では側頭骨亜全摘が第一選択 であると述べ，中井ら ${ }^{18)}$ は硬膜浸潤例であ良好 な結果を得た 1 例を報告しているが，広範な手 術例が必ずしあ良い結果をあたらすとはいえ ず31)，その適応は慎重でありたいという意見が 主流のようである.

一般に側頭骨悪性腫瘍治療上のネックは頭蓋 底破壊例であり，その術前診断が困難であるう $亢^{35)}$, 仮に頭蓋底破壊が診断されても広範な破 壊例に対する有効な治療法が未だに確立されて いないことが問題である。この点が中耳癌の予 後改善の課題であろう.

すべからく悪性腫瘍は早期発見が重要であ り, 聴器癌屯例外ではない. ことに外耳道癌で は早期発見により，充分に治癒を期待できるの で，できるだけ早期の確実な診断が予後向上の 基本であることを強調したい.

\section{まとめ}

1) 中耳癌は頭蓋底破壊を伴いやすく, 予後 不良である。

2) 外耳道癌は外耳道長軸方向より，むしろ 外耳孔を中心して浅層を放射状に拡大する傾 向がみられた。

3 ）中耳癌にあっては頭蓋内浸潤の有無, 外 耳道癌にあってはその浸潤範囲が直接予後を左 右すると考えられた。

4) 外耳道癌の治療は手術を主体とし，放射 線を併用することで良好な結果が得られた。こ の要因は放射線が有効であるととと，中耳癌に 比すると全摘が充分可能であるととによるあの と考えられた.

\section{参考文献}

1) 犬山征夫, 他 : 聴器癌の治療成績之最近の治療方 針について. 臨床耳科 $13: 396 〜 397,1986$.

$2 ）$ 鳥山寧二, 他 : 外耳道癌腫の 1 例. 日耳鼻 63 :
148 151, 1943.

3) 小出 靖: 耳癌腫治療の現状之自験例の反省. 耳 鼻臨床 $61: 35 \sim 48,1968$.

4) 隱明寺覚, 他：聴器悪性腫瘍の 4 例. 耳展 7 : 206 217, 1964.

5 ) 竹山 勇, 他 : 中耳癌に対する手術療法. 臨床耳 科 $11: 50 \sim 51,1984$.

6 ）山下隆司, 他：側頭骨を広範に破壊した中耳癌の 1 例. 臨床耳科 $13: 394 \sim 395,1986$.

7) 土井勝美, 他: 聴器癌の 2 症例. 臨床耳科 13 : 398 399, 1986.

8 ）馬場廣太郎, 他：最近経験した中耳癌の 4 症例に ついて. 耳喉 $44: 249 \sim 255,1972$.

9 ) 松岡秀樹, 他：聴器癌 2 症例. 耳鼻臨床 $79: 393$ $\sim 400,1986$.

10）池田勝久, 他：耳介癌の 2 症例. 耳鼻臨床 78 ： 1599 1602, 1985.

11) Rossenwasser $\mathrm{H}$ and Parisier SC:Tumors of the middle ear and mastoid. Otolaryngology (ed by Paparella and Shumrick). pp 1576 1599, Saunders, Philadelphia, 1980.

12) 原田勇彦, 他：聴器悪性腫湯. 耳喉 $50: 47 \sim 58$, 1978.

13）安斎友博, 他: 聴器悪性腫瘍の臨床的観察. 耳鼻 臨床 $78: 946 \sim 954,1985$.

14) Lewis JS : Cancer of the ear. A report of 150 cases. Laryngoscope $70: 551 \sim 579,1960$.

15) Boland J, et al : Cancer of the middle ear and auditory meatus. J Laryngol Otol $69: 468 \sim$ 478, 1955.

16）梅谷芳雄, 他: 聴器悪性腫瘍の 5 症例. 耳鼻臨床 $76: 1383 \sim 1390,1983$.

17) Goodwin WJ, et al : Malignant neoplasms of the external auditory canal and temporal bone. Arch Otolaryngol $106: 675 \sim 679,1969$.

18）中井義明, 他 : 聴器癌におりる側頭骨全摘術. 耳 喉 $47: 325 \sim 331,1975$.

19）齐藤龍介, 他：聴器扁平上皮癌における側頭骨病 理組織所見. 耳喉 $55: 405 \sim 410,1983$.

20) 白幡雄一：聴器原発癌の臨床, 特にその文献的考 察. 耳展 $17: 675 \sim 689,1974$.

21）切替一郎, 他: 中耳癌の臨床的観察. 耳展 1 : 326〜333, 1958.

22) Figi FA, et al : Cancer and chemodectoma in 
the middle ear and mastoid. JAMA 156:1157 〜162, 1954.

23) Brunner $\mathrm{H}$ : Basal-cell carcinoma of the external canal and middle-ear. Arch Otolaryngol 58 : $665,1953$.

24）本田哲朗, 他：外耳道癌の治療経験. 耳展 25 : 385 390, 1982.

25）齋藤春雄, 他：外耳道原発扁平上皮癌. 耳鼻臨床 $76: 2682 \sim 2687,1983$.

26) Parson $H$ and Lewis JS : Subtotal resection of the temporal bone for cancer of the ear. Cancer $7:$ :995 1001, 1954.

27) Conley JJ, et al : The surgical treatment of malignant tumors of the ear and temporal bone. Arch Otolaryng $71: 635 \sim 652,1960$.

28) Arian $S$, et al : Radical en block resection of the temporal bone. Amer J Surg 142:443 447, 1981.

29) Hanna DC, et al: A suggested technic for resection of the temporal bone. Am J Surg $114: 553 \sim 558,1967$.

30) Goodman $M$ : Management of malignancy of the temporal bone. Laryngoscope $87: 1622 \sim$ 1634, 1977.

31）豊田弥八郎, 他 : 聴器癌の臨床像. 耳喉 49:993 〜998, 1977.

32）加藤昌樹, 他：中耳扁平上皮癌の 6 症例. 耳鼻臨 床 $80: 1233 \sim 1242,1987$.

33) Fairman HD : Cancer of the middle ear. Proc Roy Soc Med 65:247〜248, 1972.

34）斉藤龍介，他：聴器扁平上皮癌の臨床と側頭骨病 理所見. 岡山医学会雑誌 $96: 263 \sim 269,1984$.

35）山本香列，他：耳介を除く聴器悪性腫瘍. 耳鼻 $26: 314 \sim 320,1980$.

$\left(\begin{array}{l}\text { 原稿採択 : 昭和 } 63 \text { 年 } 9 \text { 月 } 5 \text { 日 } \\ \text { 別刷請求先 : 佐藤公輝 } \\ \text { 个010 北海道札幌市北 } 14 \text { 条西 } 7 \text { 丁目 } \\ \text { 北海道大学医学部耳鼻咽喉科学教室) }\end{array}\right)$ 